https://doi.org/10.52058/2786-4952-2022-2(7)-769-778

Шестакова Світлана Олександрівна кандидат філологічних наук, доцент кафедри державно-правових дисциплін та українознавства, Сумський національний аграрний університет, вул.Г.Кондратьєва, 160, м. Суми, 40022, тел.: (095) 411-58-54, https://orcid.org/0000-0003-4640-0379.

\title{
ФОРМУВАННЯ ЛІНГВОРИТОРИЧНОЇ КОМПЕТЕНТНОСТІ СТУДЕНТІВ НЕГУМАНІРНОГО ПРОФІЛЮ ШЛЯХОМ ВИКОРИСТАННЯ МУЛЬТИМЕДІЙНИХ ПРЕЗЕНТАЦІЙ
}

Анотація. У статті досліджується один із засобів формування лінгвориторичної компетентності майбутніх фахівців будь-якого профілю мультимедійні презентації. Доводиться, що досягнення програмних результатів навчання, передбачених стандартами вищої освіти, можливе за умови активного використання комп'ютерних технологій, а сформована лінгвориторична компетеність забезпечує ефективне оволодіння багатьма іншими загальними компетентоностями, які $\epsilon$ спільними для більшості стандартів здобуття вищої освіти.

Визначено, що під мультимедійною презентацією у педагогічному контексті слід розуміти один із універсальних засобів навчання, який являє собою поєднання комп'ютерної анімації, відео і звукового ряду, які організовані в єдину форму і супроводжують текстовий коментар із метою кращого його сприйняття слухачами.

Стверджується доречність створення під час підготовки до промови комбінованих презентацій, які являють собою інтеграцію наочних і текстових елементів, оскільки їх застосування зорієнтоване на формування позитивної навчальної мотивації, розвиток актуальних для сучасного фахівця особистісних якостей (самостійність, динамізм, комунікабельність), удосконалення лінгвістичних знань та навичок практичного їх використання

На підставі спостережень визначено основні помилки, які допускають студенти під час підготовки презентацій і виголошення доповідей, зумовлені переважно неглибоким знанням технічних та лінгвістичних вимог до презентацій.

Для оцінювання результатів виконаної роботи рекомендовано використовувати критеріальну модель, яка формує навички критичного мислення, аналітичні здібності, лінгвістичну майстерність та допопомагає формувати оцінне ставлення до продуктів власної мовленнєвої діяльності.

Зазначено, що педагогічний потенціал мультимедійних презентацій забезпечує сприятливі умови для особистісно-орієнтованого та компетентністного підходів, підвищує ефективність процесу навчання, дозволяє 
розвивати інтелектуальні та творчі здібності студентів, удосконалювати мовленнєві навички.

Ключові слова: лінгвориторична компетентність, презентація, мультимедійна презентація, критеріальна модель.

Shestakova Sviltana Olexandrivna Candidate of philological sciences, assistant professor of state legal disciplines and Ukrainian studies department, Sumy National Agrarian University, H.Kondratieva St., 160, Sumy, 40022 tel.: (095) 411-58-54, https://orcid.org/0000-0003-4640-0379.

\section{THE LINGUORHETORICAL COMPETENCE FORMATION OF STUDENTS OF NON-HUMANITARIAN PROFILE BY THE WAY OF MULTIMEDIA PRESENTATIONS APPLICATION}

Abstract. In the article one of the means of formation linguorhetorical competence of the future professionals of any profile - multimedia presentations are researched. It is proved that the achievements of program results of studying predicted the higher education standards is possible by the conditions of active usage computer technologies and has formed the linguorhetorical competence provides the effective mastering of many other general competences which are common for the major standards of getting higher education.

It is determined that multimedia presentation in a pedagogical context should be understood as a universal means of teaching which joins computer animation, videoand audio- row which are united in one form and accompany the text comment with the purpose of better perception by listeners.

It confirms the relevance creation during the preparation for the combined presentations speech which presents the integration of visual and textual elements, whereas their usage is oriented on the formation of positive learning motivation, development actual for the modern professional personal qualities (self-determination, dynamism, sociability), improvement the linguistic knowledge and skills of their practical application.

Based on observations, the main mistakes were identified which made students during preparing presentations and pronounce reports due mainly to the non-deep knowledge of technical and linguistic requirements for presentations.

For making results of done work is recommended to use the criteria model which forms the skills of critical thinking, analytical abilities, lingual mastery and helps to form valuable relation to the productive own language activity.

It is marked that the pedagogical potential of multimedia presentations provides favorable conditions to the personal-oriented and competence approach, increases the effectiveness of the learning process, allows developing of students' intellectual and creative abilities, and improves language skills.

Keywords: the linguorhetorical competence, presentation, multimedia presentation, the criteria model. 
Постановка проблеми. Система вищої освіти України, перебуваючи в умовах активного застосуваня інформаційних та комунікаційних технологій, зазнає суттєвих трансформацій. За таких обставин вбачається важливим не тільки зберегти накопичений педагогічний досвід, але й через широке застосування сучасних засобів навчання підвищити рівень професійної культури студента як обов'язкової умови його творчої самореалізації i подальшого професійного зростання.

Не викликає сумніву той факт, що досягнення програмних результатів навчання, передбачених чинними стандартами вищої освіти для різних спеціальностей, є можливим лише за умови активного використання сучасних комп’ютерних технологій, які зумовлюють появу нової системи знань, зміну свідомості, переосмислення усієї картини світу. 3 огляду на те, що від спеціаліста будь-якої галузі вимагається наявність сформованої здатності до точного сприйняття інформації, іiі аналізу і якісного пояснення іншим, умінь публічно повідомляти про результати своєї діяльності, доступно доносити інформацію до колег і клієнтів, актуальним вбачається визначення переваг i дидактичних можливостей мультимедійних презентацій, які широко застосовуються в різних видах навчальної діяльності, надаючи можливості для зміни форм і методів роботи, істотної трансформації, збагачення освітніх парадигм та сприяючи формуванню зазначених навичок.

Аналіз останніх досліджень і публікацій. Мультимедійні презентації як один із ресурсів навчальної роботи були предметом наукової уваги таких українських i зарубіжних науковців, як Г. В. Бачурін, Л.О. Бєлясва, Н. В. Іванова, Д. С. Лебедєва, С.Б. Літвінчук, А.І. Могильник, О. П.Мокрогуз, О. В. Попкова, П.В. Сисоєв, Н.В.Сорокіна, Ю.Б.Феденєєва, Н. В. Чуркіна та інших. Проте деякі аспекти досліджуваної проблеми потребують додаткової наукової уваги.

Формулювання цілей дослідження. Метою нашого дослідження $\epsilon$ доведення важливості застосування мультимедійних презентацій для формування лінгвориторичної компетентності спеціаліста будь-якої галузі.

Виклад основного матеріалу. Сучасні стадарти вищої освіти для спеціальностей будь-якого профілю передбачають формування в майбутнього спеціаліста загальнокультурних та професійних компетенцій, важливою підставою для здобуття яких визнається сформованість лінгвориторичної компетентності. Не вдаючись до наукових дискусій, на підставі раніше здійсненого дослідження, під поняттям «лінгвориторична компетентність» автор пропонує розуміти сукупність сформованих якостей особистості, які визначають $\dddot{11}$ здатність до застосування отриманих мовленнєвих та риторичних знань i навичок та базуються на іiі моральних принципах $\mathrm{i}$ здібностях; сукупність лінгвориторичних умінь вирішувати за допомогою мовних засобів завдання спілкування в конкретних професійних ситуаціях; уміння створювати, вимовляти і осмислювати текст відповідно до мети і ситуації професійного спілкування; володіння нормами етикету і рефлексії [1, с.34]. Сформованість 
лінгвориторичної компетеності, на нашу думку, забезпечує ефективне оволодіння навичками до пошуку, оброблення та аналізу інформації з різних джерел, спілкування з представниками інших професійних груп різного рівня, командної роботи, формування здатності бути критичним і самокритичним тощо, які є спільними для більшості стандартів здобуття вищої освіти.

Однією із дисциплін гуманітарного блоку, яка активізує процеси сприйняття i трансформації разних текстів, а також продукування усних i письмових висловлювань різих жанрів, є дисципліна «Сучасне ораторське мистецтво», яка, на нашу думку, несправедливо віднесена до блоку вибіркових дисциплін, проте слід визнати, що таке рішення надало можливість використовувати іï дидактичний потенціал для формування лінгвориторичних умінь і навичок у студентів усіх спеціальностей, а не лише гуманітарного спрямування.

Під час опанування зазначеної дисципліни, серед іншого, формуються й уміння готувати текст виступу, виголошувати публічну промову на задану тему, регулювати свій емоційний стан під час спілкування 3 публікою, оцінювати аудиторію, взаємодіяти 3 нею, моделювати мовлення залежно від реакції аудиторії тощо. 3 цією метою використовуються комплексні завдання, які передбачають, зокрема, підготовку мультимедійної презентації.

Термін «презентація», за твердженням Ю.А. Маковецької-Гудзь, треба розуміти у двох значеннях. Згідно з першим презентація розглядається і як публічний виступ перед широкою аудиторією, який передбачає вміння переконувати та впливати на аудиторію, і як повідомлення, що містить нову ідею, iï пояснення, свіжу інформацію, демонструє матеріал для подальшого обговорення та усвідомлення. У другому значенні презентація - це набір мультимедійних слайдів, призначених для демонстрації за допомогою комп'ютера [2].

У науковій літературі трапляються такі синоніми до терміна «презентація» у другому значенні, як «комп’ютерна презентація», «навчальна презентація» та «мультимедійна презентація».

Ми погоджуємося 3 думкою Н.В.Сорокіної, яка під презентацією розуміє мультимедійний продукт, що створений 3 допомогою програми Microsoft PowerPoint, у якому використовуються технологічні можливості подання мультимедійної інформації, щоявляє собою послідовність слайдів, тобто електронних сторінок, які змінюють одна одну. Використання Microsoft Power Point, що входить до складу пакету Microsoft Office, не потребує значної підготовки для оволодіння навичками користування нею, не вимагає багато часу для створення презентації [3]. Подібне визначення знаходимо і в офіційних рекомендаціях щодо створення презентацій. Автори збірника під мультимедійною презентацією розуміють програму, яка може містити текстові матеріали, фотографії, малюнки, діаграми та графіки, слайд-шоу, звукове оформлення і дикторський супровід, відеофрагменти й анімацію, тривимірну графіку. Основною відмінністю презентацій від решти способів представлення 
інформації є їх особлива насиченість змістом та інтерактивність, тобто здатність певним чином змінюватися й реагувати на дії користувача [4]. Більш стисле визначення навчальних мультимедійних презентацій пропонують Л.Гаврілова, І.Хижняк : «презентації - це засіб унаочнення теоретичного матеріалу в ході його подання〉 [5, с.362]. Отже, під мультимедійною презентацією розуміємо один із універсальних засобів навчання, який являє собою поєднання комп'ютерної анімації, відео і звукового ряду, які організовані в єдину форму і супроводжують текстовий коментар із метою кращого його сприйняття слухачами.

Не можна не погодитися із Н.В.Сорокіною, яка за використанням мультимедійних елементів поділяє презентації на: 1) наочні; 2) текстові; 3) комбіновані. Найбільш доречним вважаємо використання під час викладання дисципліни комбінованих презентацій, які, за словами дослідниці, являють собою інтеграцію наочних і текстових елементів. Створення комбінованої мультимедійної презентації вимагає активної когнітивної діяльності, динамічності, організованості, сконцентрованості. Водночас поєднання різних видів подання презентаційного матеріалу ініціює інтерес до навчання, стимулює підвищення мотивації. 3 огляду на це вважаємо доречним використання комбінованих презентацій у процесі викладання дисципліни «Сучасне ораторське мистецтво», оскільки їх застосування зорієнтоване на формування позитивної навчальної мотивації, розвиток актуальних для сучасного фахівця особистісних якостей (самостійність, динамізм, комунікабельність), удосконалення лінгвістичних знань та навичок практичного їх використання [3, с.59-60].

Отже, доцільність використання мультимедійних презентацій здобувачами вищої освти у процесі навчання не викликає сумніву з огляду на специфічні можливості надання інформації, до яких належать: багатоканальність (аудіальний та візуальний канали), наочність, інтерактивність тощо. Проте весь широкий потенціал цього навчального інструменту не завжди використовується в повному обсязі.

Моніторинг якості виконання комплексних навчальних завдань здійснювався на базі Сумського НАУ у процесі викладання дисципліни «Сучасне ораторське мистецтво» для студентів 2 курсу інженернотехнологічного, економічного, біолого-технологічного факультетів, факультетів агротехнологій та природокористування і ветеринарної медицини (загальна кількість студентів - 53).

Як відомо, робота над створенням презентації починається з підготовчого етапу, на якому студент здійснює пошук, аналіз і відбір інформаційних ресурсів, переважно у глобальній мережі Інтернет. Це зумовлює підвищення активності пізнавальної діяльності, формує уміння спостерігати, розпізнавати помилки, критично аналізувати матеріал, оскільки якість багатьох ресурсів, як стверджують П. Сисоєв та М. Свстигнєєв, на достатньо низькому рівні [6]. Інформація, яка міститься на сайтах, часто являє собою автоматизований переклад текстів 3 інших мов і містить значну кількість орфографічних, 
лексичних, граматичних помилок тощо. Доцільність використання таких ресурсів, незважаючи на їх недосконалість, на нашу думку, полягає у сприянні формуванню лінгвістичної компетентності студентів

У процесі аналізу матеріалу автор презентації визначає, яка інформація має бути відображена в тексті виступу, а яка - на слайдах, що ілюструють i супроводжують його. У підсумку необхідно підготувати i наочний ряд, i текстовий коментар, які у сукупності і являтимуть собою презентацію з певної теми. Слід погодитися із тими науковцями, які вважають, що безперечна перевага у використанні презентацій полягає в перенесенні акцентів із вербальних методів навчання на методи пошукової і творчої діяльності [7].

Залежно від виду виступу і для максимальної ефективності роботи студентам пропонуються теми, які передбачають як самостійний пошук наукової літератури, так і теми із запропонованим списком наукових джерел.

Зокрема, перші теми, із яких студенти готують презентації, пов'язані із діяльністю відомих ораторів: від Давньої Греції до сучасності. Студенти обирають із наданого викладачем списку імен (Демосфен, Сократ, Аристотель, Д.Карнегі, С.Джобс, Ф.Прокопович, Т.Шевченко, В.Зеленський, П.Порошенко...) і починають підготовку: вивчають життя і діяльість обраного ритора як за різноманітними джерелами, так i за текстами їх виступів. Зауважимо, що підготовка презентації на цю тему сприяє формуванню навичок колективної роботи. Група студентів із 3 осіб обирає одну тему, наприклад, «Демосфен - найвідомішиій оратор Давньої Греції». Студентам надається можливість самостійно визначити склад своєї групи. Робота над спільним проєктом розвиває навички співпраці, ведення діалогу під час колективної творчої діяльності. Розподіл ролей і обов'язків під час виконання групового завдання визначається студентами, оскільки у групі є представники різних факультетів, часто не знайомі між собою. Згідно із нашими спостереженнями групові презентації є більш цікавими за змістом, оформленням і поданням матеріалу порівняно із індивідуальними, оскільки кожен студент відповідає за найбільш прийнятний для нього напрям роботи.

Друга група завдань пов’язана із темою «Види сучасного красномовства». Студенти на вибір готують промову агітаційного чи суспільного важливого характеру, наприклад «Сортування сміття- користь чи зайві клопоти?», «Чому для навчаня варто обрати СНАУ?», «Чи варто організовувати притулки для покинутих тварин?», «Альтернативна енергетика - за і проти», «Електромобілі за i проти» тощо. Слід зазначити, що здебільшого студенти для виступу обирають тему, яка корелюється 3 майбутньою професійною діяльністю і $\epsilon$ актуальною та цікавою для них.

Щодо двох зазначених видів виступів зауважимо, що перед студентами ставилося завдання використовувати не лише традиційні ілюстрації у вигляді фотокарток, картинок, рисунків, графіків, таблиць, а й нестандартних творчих рішеньі прийомів, які мають захопливий для слухача художній ефект і значний емоційний вплив. Так, пропонувалося використати нестандартні кольорові 
рішення, короткі (максмум 1 хв.) уривки із фільмів чи відеозаписів промов, доречні спецефекти, музичний супровід. Обов'язковим було вживання в тексті виступу тропів і мовних фігур: епітетів, метафор, порівнянь, алегорій, гіпербол, уособлень, а також фразеологізмів, аофризмів, прислів їв тощо.

Третьою $\mathrm{i}$, як показує аналіз, найскладнішою групою $\epsilon$ презентації $\mathrm{i}$ доповіді на наукову тематику. Студентами пропонується 5 тем загального характеру на вибір («Способи боротьби із професійним стресом», « Конфлікт у трудовому колективі та шляхи його вирішення», «Культура віртуального спілкування», «Синдром професійного вигоряння: шляхи попередженя», «Академічна доброчесність - шлях до змін у вищий освіті»), до кожної теми викладач допомагає укласти план i дібрати список літератури 3 метою подальшого визначення правильності структури і змісту наукової промови на обрану тему.

До цього виду презентацї висувалися дещо інші вимоги. Зокрема, суворий академічний підхід, уникнення багатослів'я, повне дотримання норм наукового стилю (відсутність емоційності, образності), стисле і конкретне визначення мети і завдань, чіткий, точний виклад матеріалу дослідження і його результатів, відповідність висновків меті і завданням роботи. Обов'язковим є дотримання структури наукового тексту.

М.Онищенко справедливо вважає наукову презентацію «найкращим i найбільш ефективним способом проінформувати про зміст дослідження; чітко, швидко й концентровано передати найбільш важливі факти, твердження, ідеї чи пропозиції та переконати в достовірності й обгрунтованості отриманих результатів. Основою підготовки презентації дослідниця визнає наукову доповідь - короткий виклад суті проведеного дослідження, отриманих результатів, їхнього теоретичного і практичного значення» [8].

Справді, створення наукової презентації має на меті унаочнити потрібну інформацію, полегшити сприймання текстового коментаря, сфокусувати увагу на головному. Проте трапляється, що наявність презентації навпаки псує враження від доповіді та залишає слухачів байдужими. Недбале і безвідповідальне ставлення до підготовки наочного супроводу (обмеження, наприклад, лише текстовою інформацією) для виголошення будь-якого виду виступу зумовлює зниження ефективності цього виду роботи. Згідно із нашими спостереженнями причинами цього є:

- невідповідність кількості слайдів регламенту ( 1 слайд - 1 хвилина). Висока швидкість зміни слайдів ускладнює, а іноді й унеможливлює сприйняття матеріалу, оскільки отримуємо наявність кількох потоків інформації: вербального і зорового, темп подання яких не збігається;

- перевантаження слайдів інформаційними об'єктами;

- неправильне оформлення слайдів , порушення законів колористики, необгрунтоване використання спецефектів, неструктурованість інформації, використання дрібного шрифту тощо;

- повний збіг матеріалів на слайді і тексту повідомлення;

- недотримання єдиного стилю оформлення слайдів; 
- значна кількість мовних помилок;

- порушення структури виступу, невідповідність змісту визначеним частинами наукового тексту, порушення логіки викладу;

- використання неякісної техніки для демонстрацій.

Наголосимо, що під час оформлення слайдів важливо дотримуватися орфографічних, пунктуаційних, лексичних, синтаксичних, стилістичних норм тощо. Основна мовна вимога до слайдів, яка сприяє формуванню лінгвістичної компетентності, - грамотність, оскільки, як справедливо зауважує М.Онищенко, помилки, неточності в цифрах або невідповідності в тексті на екрані стають набагато помітнішими [8,c.44]. Крім того, мовна майстерність полягає також у доречному використанні мовних фігур і тропів для досягнення максимального ефекту впливу на почуттєвий світ слухача.

Якість підготовчої роботи студентів перевіряється у процесі їх виступів перед аудиторією. Кожен слухач отримує аркуш із зазначеними критеріями, за кожен із яких ставиться оцінка від 0 до 5 балів. Максимальна сума балів 25. Оцінюється навчальний виступ за кількома критеріями, зокрема:

1 Змістовність виступу: відповідність усіх компонентів змісту презентації темі i проблемі, взаємозв'язок i завершеність кожної із частин виступу, логічність викладу матеріалу, достовірність (переконливість прикладів, сильні аргументи тощо), дотримання обсягу структурних частин.

2. Ергономіка презентації (відповідність технічним вимогам). Правильність використання наочного матеріалу (оформлення відповідає темі і проблемі, співвідношення текстового та ілюстративного матеріалу дозволяє забезпечити інформативність презентації, кількість слайдів відповідає регламенту, коректність обраного розміру шрифту (легке зорове сприйняття), контролювання часу виступу (порушення регламенту).

3. Культура мовлення (відсутність орфографічних, пунктуаційних, лексичних, синтаксичних, стилістичних помилок, доречне використання мовних фігур і тропів);

4. Майстерність виголошення промови (уміння вільно викладати думки, не читати текст, дотримання рекомендацій щодо техніки мовлення (інтонація, логічні і психологічні паузи, темп мовлення, активне використання голосових можливостей (зміни висоти і гучності), доречність емоційності, артистизм (для деяких видів промов), уникнення озвучених пауз и коректність невербальної поведінки (міміка, жести, поза, погляд, відстань між оратором i аудиторією), контакт з аудиторією.

5. Реакція на питання аудиторії (отримання відповіді чи її відсутність).

Приклад аркуша оцінювання

\begin{tabular}{|l|l|l|l|l|l|l|}
\hline $\begin{array}{l}\text { Прізвище } \\
\text { доповідача }\end{array}$ & Змістовність & Ергономіка Культура & $\begin{array}{l}\text { Виголошення } \\
\text { мовлення }\end{array}$ & $\begin{array}{l}\text { Реакція номови } \\
\text { питання }\end{array}$ & Усього \\
\hline $\begin{array}{l}\text { 1. Егорова } \\
\text { Свгенія }\end{array}$ & 4 & 4 & 2 & 2 & 0 & 12 \\
\hline $\begin{array}{l}2 . \quad \text { Легка } \\
\text { Софія }\end{array}$ & 4 & 5 & 4 & 4 & 2 & 19 \\
\hline $\begin{array}{l}3 . \quad \text { Корольова } \\
\text { Юлія }\end{array}$ & 5 & 5 & 5 & 5 & 5 & 25 \\
\hline
\end{tabular}


Справедливою вважаємо за можливе визнати тезу Н.А.Юшкової, яка стверджує, що регулярне використання критеріальної моделі оцінювання виступів із використанням мультимедійних технологій дозволяє організувати неформальне залучення студентів до роботи, формує в них навички критичного мислення, розвиває аналітичні здібності та мовну майстерність. До того ж, на думку дослідниці, сформованість оцінного ставлення до продуктів власної мовленнєвої діяльності (письмових і усних) вкрай важливе для становлення мовної особистості майбутнього фахівця [9].

Висновки. Таким чином, підсумовуючи, вважаємо за можливе стверджувати, що застосуванняя мультимедійних презентацій під час вивчення дисципліни «Сучасне ораторське мистецтво» позитивно впливає на процес навчання, оскільки стимулює такі когнітивні аспекти навчання, як сприйняття i аналіз інформації, підвищує мотивацію студентів, розвиває навички колективної співпраці, удосконалює уміння створювати і виголошувати тексти, підвищує інформаційну культуру, формує мовленнєву i риторичну компетентність студентів тощо. Отже, педагогічний потенціал мультимедійних презентацій забезпечує сприятливі умови для особистісно-орієнтованого та компетентністного підходів і підвищує ефективність процесу навчання. Крім того, застосування мультимедійних презентацій дозволяє розвивати інтелектуальні та творчі здібності студентів, впливати на їх ціннісні настанови i переваги та в цілому забезпечувати динаміку у становленні професійно значущих особистісних якостей майбутніх фахівців.

\section{Лimepamypa:}

1. Шестакова С.О. Лінгвориторична компетентність як запорука професійного успіху юриста. Приватне та публічне право. 2020. № 2. C.32-36. URL: http://pp-law.in.ua/archive/ 2_2020/8.pdf.

2. Маковецька-Гудзь Ю.А. Мультимедійна презентація як спосіб спілкування з аудиторією. Новітні освітні технологї: наук.-практ.конф. URL: http://confesp.fl.kpi.ua/node/1248.

3. Сорокіна Н.В. Формування професійної іншомовної компетентності майбутніх філологів засобами мультимедійних технологій: дис...кандидата пед.наук: 13.00.04. Київ, 2016 URL: https://npu.edu.ua/images/file/vidil_aspirant/dicer/D_26.053.01/Disser_Sorokina.pdf

4. Рекомендації щодо оформлення мультимедійних презентацій. URL: http://man.gov.ua/upload/activities/Masterklass/Yunomu\%20doslidnyku/Rekomend_multimed.PDF

5. Гаврілова Л., Хижняк I. Класифікація лекційних презентацій та вимоги до них. Вісник Львівського університету. Серія філологічна. 2010. Вип.50. С. 361-367. URL:

http://litmisto.org.ua/?p=19616

6. Сысоев П.В., Евстигнеев М.Н. Использование современных учебных Интернетpeсурсов в обучении иностранному языку и культуре. URL: https://cyberleninka.ru/article/n/ ispolzovanie-sovremennyh-uchebnyh-internet-resursov-v-obuchenii-inostrannomu-yazyku-i-kulture.

7. Резинькова С.В. Использоваине компьютерных презентаций на уроках английского языка. Фестиваль педагогических идей «Открытый урок». URL: festival.1september.ru/articles/605335/.

8. Онищенко М. Презентація як засіб відтворення ідеї. Збірник наукових праць. Вип. 26. Харків, 2017. URL: https://goik.univer.kharkov.ua/wp-content/files/issue_26/26_9.pdf.

9. Юшкова Н.А. Развитие компетенций студентов-юристов в работе с мультимедийными презентациями . URL: https://cyberleninka.ru/article/n/razvitie-kompetentsiystudentov-yuristov-v-rabote-s-multimediynymi-prezentatsiyami). 


\section{References:}

1. Shestakova, S.O. (2020). Lingvory`tory`chna kompetentnist` yak zaporuka profesijnogo uspixu yury`sta [Linguistic competence as a guarantee of professional success of a lawyer]. Pry`vatne ta publichne pravo - Private and public law, 2, 32-36. Retrieved from http://pplaw.in.ua/archive/2_2020/8.pdf [in Ukrainian].

2. Makovecz`ka-Gudz`, Yu.A. Multy`medijna prezentaciya yak sposib spilkuvannya z audy toriyeyu [Multimedia presentation as a way to communicate with the audience]. Novitni osvitni texnologiyi: nauk.-prakt.konf. - The latest educational technologies: Scientific and Practical Conference. Retrieved from http://confesp.fl.kpi.ua/node/1248 [in Ukrainian].

3. Sorokina, N.V. (2016). Formuvannya profesijnoyi inshomovnoyi kompetentnosti majbutnix filologiv zasobamy` mul ty`medijny`x texnologij [Formation of professional foreign language competence of future philologists by means of multimedia technologies]. Candidate's thesis. Kyiv. Retrieved from https://npu.edu.ua/images/file/vidil_aspirant/dicer/D_26.053.01/Disser_Sorokina.pdf [in Ukrainian].

4. Rekomendaciyi shhodo oformlennya mul'ty`medijny`x prezentacij [Recommendations for the design of multimedia presentations]. Retrieved from http://man.gov.ua/upload/activities/Masterklass/Yunomu\%20doslidnyku/Rekomend_multimed.PDF [in Ukrainian].

5. Gavrilova, L., \& Xy`zhnyak, I. (2010). Klasy`fikaciya lekcijny`x prezentacij ta vy`mogy do ny`x [Classification of lecture presentations and requirements for them]. Visny`k L'vivs`kogo universy`tetu. Seriya filologichna - Bulletin of Lviv University. Philological series, 50, 361-367. Retrieved from http://litmisto.org.ua/?p=19616 [in Ukrainian].

6. Susoev, P.V., \& Evsty`gneev, M.N. Y`spol'zovany`e sovremennыx uchebnыx Y`nternetresursov v obucheny'y' y'nostrannomu yazыku y' kul ture [The use of modern educational Internet resources in teaching a foreign language and culture]. Retrieved from https://cyberleninka.ru/article/n/ispolzovanie-sovremennyh-uchebnyh-internet-resursov-vobuchenii-inostrannomu-yazyku-i-kulture [in Russian].

7. Rezy`n`kova, S.V. Y`spol`zovay`ne komp`yuternыx prezentacy`j na urokax angly`jskogo yazыka [Use of computer presentations in English lessons]. Festy`val pedagogy`chesky`x y`dej «Otkrbitbij urok» - Festival of Pedagogical Ideas "Open Lesson". Retrieved from festival.1 september.ru/articles/605335/[in Russian].

8. Ony`shhenko, M. (2017). Prezentaciya yak zasib vidtvorennya ideyi [Presentation as a means of reproducing an idea]. Zbirny`k naukovy`x pracz` - Collection of scientific works, 26. Kharkiv. Retrieved from https://goik.univer.kharkov.ua/wp-content/files/issue_26/26_9.pdf [in Ukrainian].

9. Yushkova, N.A. Razvy`ty`e kompetency`j studentov-yury`stov $v$ rabote $s$ mul'ty`medy`jnыmy` prezentacy`yamy` [Development of competencies of law students in working with multimedia presentations]. Retrieved from https://cyberleninka.ru/article/n/razvitiekompetentsiy-studentov-yuristov-v-rabote-s-multimediynymi-prezentatsiyami) [in Russian]. 